\title{
Profile of Pulmonary Tuberculosis Patients with Type 2 Diabetes Mellitus in Pulmonary Department Dr. Soetomo General Hospital Surabaya
}

\author{
Ayu Rahmanita Putri Soetrisno ${ }^{1 *}$, Rebekah Juniati Setiabudi ${ }^{2}$ Laksmi Wulandari $^{3}$ \\ ${ }^{1}$ Faculty of Medicine, Universitas Airlangga, Surabaya, Indonesia. \\ ${ }^{2}$ Department of Microbiology, Faculty of Medicine, Universitas Airlangga/Dr. Soetomo, Surabaya, Indonesia. \\ ${ }^{3}$ Department of Pulmonology and Respiratory Medicine, Faculty of Medicine, Universitas Airlangga/Dr. Soetomo, \\ Surabaya, Indonesia.
}

\section{ARTICLE INFO}

Article history:

Received 21 October 2019

Received in revised form 20

November 2019

Accepted 18 May 2020

Available online 30 May 2020

\section{Keywords:}

Mycobacterium tuberculosis,

Diabetes mellitus type 2,

Profile.

\begin{abstract}
Background: Pulmonary tuberculosis (TB) is the most important infectious disease, caused by Mycobacterium tuberculosis (MTB). Indonesia is the third country with the most prevalent TB cases in the world. Not all people who were exposed to MTB will become active TB, because the immune response is the main determinant. Immunocompromised person, such as patients who have type 2 diabetes mellitus (DM) as a comorbid are more prone to develop active TB infection. This study aimed to analyze the profile of pulmonary TB patients with type 2 DM in Pulmonary Department Dr. Soetomo General Hospital Surabaya.

Methods: This was an observational descriptive study with a cross-sectional design. The research data were obtained from the medical records of TB patients with type 2 DM in Pulmonary Department Dr. Soetomo General Hospital Surabaya in January December 2017.

Results: Out of a total of 414 hospitalized patients, 74 patients with pulmonary TB were found with type $2 \mathrm{DM}$. Only 53 patients fulfilled the inclusion criteria. Gene Xpert results were sensitive $(66.7 \%)$, previous TB treatment history $(54.7 \%)$, unregulated type $2 \mathrm{DM}(88.4 \%)$, RBG with the average of $311.83 \mathrm{mg} / \mathrm{dl}$, PPBS with the average of $263.31 \mathrm{mg} / \mathrm{dl}$, FBG with the average of $238 \mathrm{mg} / \mathrm{dl}$, and $\mathrm{HbA} 1 \mathrm{C}>10 \%(68 \%)$.

Conclusion: The majority of the patients of pulmonary TB with type 2 DM have average high blood glucose and unregulated DM.
\end{abstract}

\section{INTRODUCTION}

Tuberculosis (TB) is an infectious disease caused by Mycobacterium tuberculosis (MTB). The number of TB cases in 2016 was 351,893. This disease has increased from the previous year which was recorded as many as 330,729 cases in $2015 .^{1}$ The host immune system is a major factor in determining whether a person will suffer for active TB infection or latent TB infection (LTBI). Immunocompetence immune is likely to experience LTBI, whereas immunocompromised immune is more likely to improve active TB infection.

Type 2 diabetes mellitus (T2DM) is often found in immunocompromised conditions. T2DM is caused by insulin resistance and relative insulin deficiency, resulted in high blood glucose levels ${ }^{2}$, and a long term high blood glucose levels condition will change the function of the immune system. ${ }^{3}$ Indonesia ranks the $4^{\text {th }}$ highest position in the world for prevalence of $\mathrm{DM}^{4}$ and it is estimated in the coming year of 2030, the number will increase up to 21.3 million people. ${ }^{5}$ An increasing incidence of T2DM can be associated with an increasing active pulmonary TB infection.

T2DM patients with high blood sugar levels are considered immunosuppressed due to the decreasing in Th-1, TNF-, IFN-, IL-1 $\beta$, and IL- $6^{6}$ responses and are related to host immunity in the lungs, such as adhesion replacement, the ability of phagocytosis from monocytes or macrophages and polymorphonuclear cells $(\mathrm{PMN})^{7}$, thus making the rapid development of MTB. $^{8}$ Individuals with $\mathrm{DM}$ have 2.5 times the risk of developing TB than healthy person. ${ }^{4}$ Researches on TB patients with T2DM have been widely carried out but there is no specific study that shows the results of the diagnosis of pulmonary TB and blood sugar levels of TB patients with T2DM at Dr. Soetomo General Hospital Surabaya.

*Correspondence: putriayu040998@gmail.com 


\section{METHODS}

This was an observational descriptive study with a cross-sectional design to examine secondary data, namely the medical records of pulmonary TB patients with T2DM. The population taken was pulmonary TB patients with T2DM in Pulmonary Department Dr. Soetomo General Hospital Surabaya in January December 2017. The research samples were consecutive sampling. Inclusion criteria were pulmonary TB patients (ICD A15.0) with T2DM (E11.9 T2DM without complication) in the age of 18 to 65 years old. The data were analyzed descriptively and were displayed in tables.

\section{RESULTS}

Figure 1 shows the data of hospitalized patients with TB in January - December 2017 were 414 patients, excluded by consecutive sampling into 74 pulmonary TB patients with T2DM, and excluded into 53 patients, thus inclusion criteria were fulfilled. Inclusion criteria were pulmonary TB patients (ICD A15.0) with T2DM (E11.9 T2DM without complication) in the age of 18 to 65 years old. This study used 53 research samples with secondary data, namely the medical records of the patients.

Table 1. Age and gender distribution of pulmonary TB patients with T2DM in Pulmonary Department Dr. Soetomo General Hospital Surabaya 2017

\begin{tabular}{cccc}
\hline Variable & Categories & Frequency $(\mathrm{n})$ & Percentage $(\%)$ \\
\hline Sex & Men & 33 & $62.3 \%$ \\
& Women & 20 & $37.7 \%$ \\
Age & $>40$ years old & 49 & $92.5 \%$ \\
& $<40$ years old & 4 & $7.5 \%$ \\
\hline
\end{tabular}

Table 1 shows the most dominant gender distribution was men, about 33 patients $(62.3 \%)$, while women were only 20 patients $(37.7 \%)$. The age of the dominant patient was $>40$ years old, about 49 patients $(92.5 \%)$, while 4 other patients aged $<40$ years old $(7.5 \%)$.

Table 2. Distribution table of the diagnosis of TB cases based on Gene Xpert TB/RIF of pulmonary TB patients with T2DM in Pulmonary Department Dr. Soetomo General Hospital Surabaya 2017

\begin{tabular}{lcc}
\hline & $\begin{array}{c}\text { Frequency } \\
\text { (n) }\end{array}$ & Percentage (\%) \\
\hline New cases of TB & 24 & 45.3 \\
Gene Xpert TB/RIF Sensitives & 18 & 66.7 \\
Previous TB treatment history & 29 & 54.7 \\
Gene Xpert TB/RIF Resistant & 9 & 33.3 \\
Total cases & 53 & 100 \\
Total results of Gene Xpert & 27 & 100 \\
TB/RIF & & \\
\end{tabular}

Table 2 shows the diagnosis of new TB cases was 24 patients $(45.3 \%)$, the results of Gene Xpert TB/RIF sensitive was 18 patients $(66.7 \%)$. Another case with TB that had a history of previous TB treatment was 29 patients $(54.7 \%)$, the results of Gene Xpert TB/RIF resistant was 9 patients $(33.3 \%)$. It can be concluded that the most TB patients with previous TB treatment history were 29 patients $(54.7 \%)$ and the sensitive Gene Xpert TB/RIF was 18 patients $(66.7 \%)$.

Table 3. Distribution table of T2DM category in pulmonary TB patients with T2DM in Pulmonary Department Dr. Soetomo General Hospital Surabaya 2017

\begin{tabular}{lcc}
\hline & Frequency $(\mathrm{n})$ & Percentage $(\%)$ \\
\cline { 2 - 3 } T2DM regulated & 3 & 11.6 \\
T2DM unregulated & 23 & 88.4 \\
Total & 26 & 100 \\
\hline
\end{tabular}

Table 3 shows out of 53 samples, only 26 patients had information about blood sugar regulation while 27 other patients did not have the information. Explanation based on Table 3, T2DM regulated in pulmonary TB patients with T2DM were only 3 patients $(11.6 \%)$ and $\mathrm{T} 2 \mathrm{DM}$ that were not regulated in pulmonary TB patients were 23 patients (88.4\%). Therefore, it can be concluded that the number of pulmonary TB patients with unregulated T2DM was bigger than the regulated ones.

Table 4. Distribution table of blood sugar test results conducted in pulmonary TB patients with T2DM in Pulmonary Department Dr. Soetomo General Hospital Surabaya 2017

\begin{tabular}{lccccl}
\hline $\begin{array}{l}\text { Variable } \\
(\mathrm{mg} / \mathrm{dl})\end{array}$ & $\mathrm{N}$ & \multicolumn{2}{c}{ Minimum Maximum } & Mean & $\begin{array}{c}\text { Std. } \\
\text { Deviation }\end{array}$ \\
\hline RBS & 53 & 129 & 661 & 311.83 & 124.210 \\
PPBS & 13 & 104 & 552 & 263.31 & 114.65 \\
FBS & 12 & 113 & 386 & 238.00 & 82.593 \\
\hline
\end{tabular}

Table 4 shows all samples (53 patients) had RBS examination results. The lowest value of RBS was 129 $\mathrm{mg} / \mathrm{dl}$ and the highest value was $661 \mathrm{mg} / \mathrm{dl}$. The total sample results had an average of $311.83 \mathrm{mg} / \mathrm{dl} \pm$ $124.210 \mathrm{mg} / \mathrm{dl}$.

However, post prandial blood sugars (PPBS) examination was not carried out by all samples, the data were only available in 13 patients, 40 patients had none. Based on Table 4, the lowest value of PPBS examination was $104 \mathrm{mg} / \mathrm{dl}$ and the highest value was $552 \mathrm{mg} / \mathrm{dl}$, with an average of $263.31 \mathrm{mg} / \mathrm{dl} \pm 114.65$ $\mathrm{mg} / \mathrm{dl}$.

The results of FBS examination were also not carried out by all samples, only 12 patients had the data, while 41 patients had none. Out of 12 patients, the lowest value was $113 \mathrm{mg} / \mathrm{dl}$ and the highest value was $386 \mathrm{mg} / \mathrm{dl}$. The average value of FBS was $238.00 \mathrm{mg} / \mathrm{dl}$ \pm 82.593 .

Table 5. Distribution table of HbA1C examination results in pulmonary TB patients with T2DM in Pulmonary Department Dr. Soetomo General Hospital Surabaya 2017

\begin{tabular}{lll}
\hline & Frequency (n) & Percentage (\%) \\
\hline$<6.5 \%$ & 2 & 8 \\
$8-10 \%$ & 6 & 24 \\
$>10 \%$ & 17 & 68 \\
Total & 25 & 100 \\
Lowest results & $5.8 \%$ & \\
Highest results & $13.6 \%$ & \\
Mean & $10.42 \%$ & \\
Std. Deviation & 1.96172 & \\
\hline
\end{tabular}


Table 5 shows from a total of 53 samples that had HbA1C results, only 25 patients had the information, while 28 patients had none. Explanation based on Table 5 , patients with $\mathrm{HbA1C}<6.5 \%$ were only in 2 patients (8\%), 8-10\% as many as 6 patients (24\%), and most were $>10 \%$ as many as 17 patients $(68 \%)$. The average value of $\mathrm{HbA1C}$ in this study was $10.42 \% \pm 1.96172$. However, there were 28 patients who did not have HbA1C data because there were no data on the medical records.

\section{DISCUSSION}

The sample of this study was 53 patients with dominant results is a male patients $(62.5 \%)$ and aged $>40$ years $(92.5 \%)$. A previous study from Kariadi Hospital Semarang, Central Java, in 2015 reported that out of all pulmonary TB patients with DM in 48 patients (58.5\%), 34 patients $(41.5 \%)$ were female patients. ${ }^{9}$ It stated that men are most affected by TB, because they tend to be outside the house, meet many people, and smoke, thus it is more risky and damage the respiratory system due to cigarette exposure or vehicle pollution.

The results of men aged $>40$ years old also became dominant in 2015 in Sebrang Ulu, Palembang ${ }^{10}$, while a study in India in 2018 reported that men aged $>50$ years old significantly increased the chances of morbidity of these two diseases. ${ }^{11}$ These studies are relatable because older age is more vulnerable and the physiology of the patient's respiratory system is reduced, the barrier mechanism or microbial clearance can be damaged due to aging, ${ }^{12}$ such as decreased ciliary function, pulmonary elasticity, and cough reflexes, which will increase the risk of infection with pulmonary $\mathrm{TB}^{13}$ and added to T2DM disease can cause a decrease in cellular immune system, because blood sugar levels are always high and can reduce macrophage function. ${ }^{10}$

In this study, the diagnosis of a patient's pulmonary TB was classified according to the treatment history, between new cases of TB or TB with a previous history, to make it easier to see rifampicin resistance. Gene Xpert TB/RIF has been recommended by WHO since 2010 and later in 2013 expanded its use as an initial diagnostic test in all people with signs and symptoms of TB. ${ }^{14}$ The most dominant TB diagnosis results were patients who had a history of previous treatment, that was more than $50 \%$ of all patients, and the dominant TB/RIF Gene Xpert examination was sensitive to the diagnosis of new cases of TB.

In a study conducted in 2011 , it was found that treatment failure rates were higher in pulmonary $\mathrm{TB}$ patients with DM. ${ }^{15}$ Other studies in the same year also found that DM was associated with an increased risk of recurrence. TB patients with $\mathrm{DM}$ have a risk ratio (RR) for failure and death results 1.69 times higher. ${ }^{16}$

In another study in Bangladesh conducted in 2014 , out of the total of 1,311 samples, the ones that had Gene Xpert examination results were only 154 patients (11.7\%). Out of the total of 154 patients examined by Gene Xpert TB/RIF, the ones who had DM were as many as 132 patients $(12.9 \%)$. The examination results of TB patients with DM examined by Gene Xpert TB/RIF sensitive were 129 patients (12.6\%) and Gene Xpert TB/RIF resistant were only 3 patients $(0.3 \%)$.
Patients with DM were associated with a 3-fold higher risk of rifampicin resistance, previous TB treatment, and smear positive than TB patients who had confirmed examination only. ${ }^{17}$

In this study, it is dominated by patients with unregulated T2DM, as many as 23 patients $(88.4 \%)$. TB patients with DM have higher mortality rates and deaths specifically related to TB. ${ }^{18}$ Recurrence can occur due to the association of immune function in the patient. TB patients with DM will experience a decrease in cellular immune response, namely Th- 1 , IFN- $\gamma$, IL- $1 \beta$, and TNF$\alpha$. In DM patients whose blood sugar is well regulated, IL-6 and IL-1 $\beta$ production will return to normal after 6 months. ${ }^{19}$ Therefore, controlling blood sugar is very important.

The condition of hyperglycemia or high blood sugar with a long period of time or chronic will make TB patients with DM have difficulties in suceeding TB treatment and have severe complications. Types of blood sugar tests examined in this study were RBS, PPBS, FBS, and HbA1C.

RBS is blood sugar that is checked at the time. A person with $\mathrm{RBS} \geq 200 \mathrm{mg} / \mathrm{dl}$ with other clinical symptoms such as polyuria, polydipsia, polyphagia, extreme fatigue, tingling, and other symptoms can be diagnosed with DM. ${ }^{20}$

From the results in Table 4, the average value of maximum RBS is far away from normal value, although there is a patient that has the lowest value of $129 \mathrm{mg} / \mathrm{dl}$ that cannot be categorized in the diagnosis of T2DM, but the patient's previous diagnosis was T2DM. RBS below $\leq 200 \mathrm{mg} / \mathrm{dl}$ can occur because of the possibility of the patient after being injected with insulin or given oral OAD. Other factors that affect GDA to go down or low are less food intake, alcohol, side effects from other drugs, more physical activity or exercise than usual. ${ }^{21}$

In a study conducted in 2013 in Ethiopia, the highest RBS value obtained was $>288 \mathrm{mg} / \mathrm{dl}$ of 8 patients $(14.3 \%){ }^{22}$ In addition to the high blood sugar factor, TB also worsen blood sugar regulation. TB drugs interact with DM drugs, thus it will reduce the effectiveness of TB treatment and T2DM. High RBS value is still commonly found in this study, probably because in Dr. Soetomo General Hospital Surabaya, the patient's condition was already critical and there were other complications that could worsen the condition of TB patients with DM.

Hyperglycemia in the body will affect transmission and even TB treatment. Hyperglycemia can change the immunity of TB patients through one or several metabolic consequences. ${ }^{3}$ This is indirectly supported by a consistent relationship between blood sugar or HbA1C levels and the results of immune responses in TB conditions. ${ }^{3}$ If hyperglycemia is uncontrolled, it can cause treatment failure and also the possibility of death during TB treatment in patients with comorbidities compared to normal blood sugar. ${ }^{23}$

The use of insulin is recommended in the management of DM treatment with TB in the intensive phase of TB treatment, then oral OAD can be given periodically in the advanced phase of TB treatment. ${ }^{24}$ The interaction of rifampicin as antituberculosis drug (ATD) will reduce the effectiveness or uselessness of $\mathrm{OAD}$, namely sulfonyl urea, then the dosage of OAD 
needs to be administered. ${ }^{25}$ The duration of TB treatment will reach 9 months if blood sugar levels are not well regulated. ${ }^{26}$

PPBS is a reference for regulated and unregulated blood sugar levels. It can be a determiner for the diagnosis of T2DM if PPBS value is $\geq 200 \mathrm{mg} / \mathrm{dl}^{27}$ From the results in Table 4, out of 53 patients, only 13 patients had PPBS values. The lowest PPBS value was $104 \mathrm{mg} / \mathrm{dl}$, the highest value was $552 \mathrm{mg} / \mathrm{dl}$, with the average of $263.31 \mathrm{mg} / \mathrm{dl} \pm 114.65$.

In a previous study from Kasturba Hospital India in 2018, the total sample of TB patients with DM was 184 patients. The patients who had PPBS results were 100 patients $(54 \%)$ with a median of $247.5 \mathrm{mg} / \mathrm{dl}$ and interquartile range (IQR) $173.5 \mathrm{mg} / \mathrm{dl} .{ }^{28}$ High PPBS value indicated that TB patients with DM had poorly regulated sugar control.

FBS is also included as a reference for regulated and unregulated blood sugar levels. DM can be diagnosed if the examination results of fasting blood glucose (FBG) is $\geq 126 \mathrm{mg} / \mathrm{dl}$ with some symptoms such as polyuria, polydipsia, and polyphagia. In this study, out of 53 patients, only 12 patients had FBS value. The lowest FBS was $113 \mathrm{mg} / \mathrm{dl}$, the highest was $386 \mathrm{mg} / \mathrm{dl}$, and the average was $238 \mathrm{mg} / \mathrm{dl} \pm 82.593$. The lowest result with $113 \mathrm{mg} / \mathrm{dl}$ cannot be said for the diagnosis of T2DM, but in this study all data taken had previously been diagnosed with T2DM. Low FBS value can occur after being given insulin and other oral OAD or wellregulated T2DM. T2DM which is regulated blood sugar is the average value between PPBS sugar and FBG $<140$ $\mathrm{mg} / \mathrm{dl}$.

In a study conducted in Odisha, India in 2016, the total sample of patients with TB was 101 patients. The examination results of FBS had an average of 132.4 $\mathrm{mg} / \mathrm{dl}$. This result is higher when compared to TB patients. ${ }^{29}$ Another study from Kasturba Hospital India in 2018 presented the results of $184 \mathrm{~TB}$ patients with DM. The ones who had FBS examination results were 130 patients $(71 \%)$ with median results of $167 \mathrm{mg} / \mathrm{dl}$ and IQR $130.75 \mathrm{mg} / \mathrm{dl}^{28}$

Based on the previous explanation, the average value of FBS tend to be high. This is associated with immunity in TB patients. TB patients have immunocompromise, because they have been declared as infected with TB. Against even killing $M$. tuberculosis depends on the successful interaction of macrophages infected with lymphocytes $\mathrm{T} .^{30}$

$\mathrm{HbA} \mathrm{AC}$ is considered to have the best long-term blood sugar control results. In this study, out of 53 patients, only 25 patients had the data. The results showed that patients with $\mathrm{HbA1C}>10 \%$ were 17 patients $(68 \%)$. The lowest $\mathrm{HbA} 1 \mathrm{C}$ value was $5.8 \%$ and the highest value was $13.6 \%$ with an average value of $10.42 \% \pm 1.96172$. The lowest value in this study cannot be diagnosed with DM, because the diagnosis of DM has $\mathrm{HbA} 1 \mathrm{C}$ value of $\geq 6.5 \%$. What is likely to happen with low $\mathrm{HbA} 1 \mathrm{C}$ is that patients have well-regulated blood sugar control, because in this study the results of 3 patients $(11.54 \%)$ with regulated T2DM.

In DM patients, TB can occur due to poor blood sugar control. ${ }^{31}$ Recent study from Kasturba Hospital India, $111 \mathrm{~TB}$ patients with DM (60\%) had HbA1C values between $6.5 \%-17.0 \% .{ }^{28}$ Unregulated DM is hyperglycemia Chronic disease with high $\mathrm{HbA1C}$ is associated with impaired immunity. ${ }^{29}$

\section{CONCLUSION}

Pulmonary TB patients with T2DM in Pulmonary Department Dr. Soetomo General Hospital Surabaya is dominated by men, most of the patients are $>40$ years old and more than $50 \%$ of patients are TB patients who had previous treatment history. The average patient's blood sugar level is high and are unregulated T2DM. In this condition, the patient will experience a decrease in the immune system, difficulty to regulate blood sugar that is ultimately not controlled, the risk of failure of TB treatment, the risk of recurrence, the risk of MDR TB, the risk of severe complications, and a higher risk of death than those without comorbidities. On average, the condition of the patients who are treated at Dr. Soetomo General Hospital Surabaya are already critical, they have severe complications because Dr. Soetomo General Hospital Surabaya is a central referral hospital in East Java.

\section{REFERENCES}

1. Indonesia KKR. Profil Kesehatan Indonesia 2016. Jakarta: Kementerian Kesehatan Republik Indonesia, 2017.

2. Federation ID. What is Diabetes. Brussels: International Diabetes Federation, 2018.

3. Restrepo BI and Schlesinger LS. Host-Pathogen Interactions in Tuberculosis Patients with Type 2 Diabetes Mellitus. Tuberculosis (Edinburgh, Scotland). 2013; 93 Suppl: S104.

4. Federation ID. IDF Diabetes Atlas. 8th Ed. Brussels: International Diabetes Federation, 2017.

5. Use of Glycated Haemoglobin (HbA1C) in the Diagnosis of Diabetes Mellitus. Diabetes Research and Clinical Practice. 2011; 93: 299-309.

6. Bacakoglu F, Basoglu OK, Cok G, Sayiner A and Ates M. Pulmonary Tuberculosis in Patients with Diabetes Mellitus. Respiration; International Review of Thoracic Diseases. 2001; 68: 595-600.

7. Guptan A and Shah A. Tuberculosis and Diabetes: An Appraisal. Ind J Tub. 2000; 47: 3-8.

8. Indonesia PE. Konsensus Pengelolaan dan Pencegahan Diabetes Melitus Tipe 2 di Indonesia 2015. Jakarta: PB Perkeni, 2015.

9. Zahrotun N, Fatur Nur K and Dwi N. Prevalensi Terjadinya Tuberkulosis pada Pasien Diabetes Mellitus di RSUP Dr. Kariadi Semarang. Jurnal Kedokteran Diponegoro. 2015; 4: 1714-25.

10. Novita E, Ismah Z and Pariyana P. Angka Kejadian Diabetes Melitus pada Pasien Tuberkulosis. 2018. 2018; 5: 6.

11. Sharma D, Goel NK, Sharma MK, Walia DK, Thakare MM and Khaneja R. Prevalence of Diabetes Mellitus and Its Predictors among Tuberculosis Patients Currently on Treatment. Indian J Community Med. 2018; 43: 302-6.

12. Fitri Fauzia D. Insidensi Tuberkulosis Paru pada Pasien Diabetes Melitus Tipe 2 di Ruang Rawat Inap Penyakit Dalam RSUP Dr. M. Djamil Padang. Fakultas Kedokteran, Universitas Andalas, 2016.

13. Putra BE. Pengaruh Usia terhadap Prevalensi Tuberkulosis Paru pada Pasien Diabetes Melitus Tipe 2 di Rumah Sakit Dr. Cipto Mangunkusumo pada Tahun 2010. Jakarta: Universitas Indonesia, 2012.

14. Organization WH. Fact Sheets on Tuberculosis. Geneva: World Health Organization, 2018. 
15. Chang JT, Dou HY, Yen CL, et al. Effect of Type 2 Diabetes Mellitus on the Clinical Severity and Treatment Outcome in Patients with Pulmonary Tuberculosis: A Potential Role in the Emergence of Multidrug-Resistance. Journal of the Formosan Medical Association = Taiwan Yi Zhi. 2011; 110: 372-81.

16. Baker MA, Harries AD, Jeon CY, et al. The Impact of Diabetes on Tuberculosis Treatment Outcomes: A Systematic Review. BMC Medicine. 2011; 9: 81.

17. Mehta S, Yu EA, Ahamed SF, Bonam W and Kenneth J. Rifampin Resistance and Diabetes Mellitus in a CrossSectional Study of Adult Patients in Rural South India. BMC Infectious Diseases. 2015; 15: 451.

18. Baghaei $\mathrm{P}$, Marjani $\mathrm{M}$, Javanmard $\mathrm{P}$, Tabarsi $\mathrm{P}$ and Masjedi MR. Diabetes Mellitus and Tuberculosis Facts and Controversies. Journal of Diabetes and Metabolic Disorders. 2013; 12: 58.

19. Mihardja L, Lolong DB and Ghani L. Prevalensi Diabetes Melitus pada Tuberkulosis dan Masalah Terapi. Jurnal Ekologi Kesehatan. 2015: 350-8.

20. Federation ID. Recommendations for Managing Type 2 Diabetes in Primary Care. In: Practice IC, (Ed.). Brussels: International Diabetes Federation, 2017.

21. Association AD. Factors Affecting Blood Glucose. Virginia: American Diabetes Association, 2019.

22. Amare H, Gelaw A, Anagaw B and Gelaw B. Smear Positive Pulmonary Tuberculosis among Diabetic Patients at the Dessie Referral Hospital, Northeast Ethiopia. Infect Dis Poverty. 2013; 2: 6-.

23. Agarwal AK, Gupta G, Marskole P and Agarwal A. A Study of the Patients Suffering from Tuberculosis and Tuberculosis-Diabetes Comorbidity in Revised National Tuberculosis Control Program Centers of Northern Madhya Pradesh, India. Indian J Endocrinol Metab. 2017; 21: 570-6.
24. Fahmi MA. Prevalensi Diabetes Mellitus Tipe 2 pada Pasien Tuberkulosis di Kabupaten Temanggung Jawa Tengah. Institut Ilmu Kesehatan Bhakti Wiyata Kediri, 2017.

25. Bailey SL and Grant P. 'The Tubercular Diabetic': The Impact of Diabetes Mellitus on Tuberculosis and Its Threat to Global Tuberculosis Control. Clin Med (Lond). 2011; 11: 344-7.

26. Indonesia KKR. Pedoman Nasional Pengendalian Tuberkulosis. Jakarta: Kementerian Kesehatan Republik Indonesia, 2014.

27. Ogurtsova K, da Rocha Fernandes JD, Huang Y, et al. IDF Diabetes Atlas: Global Estimates for the Prevalence of Diabetes for 2015 and 2040. Diabetes Res Clin Pract. 2017; 128: 40-50.

28. Pande T, Huddart S, Xavier W, et al. Prevalence of Diabetes Mellitus amongst Hospitalized Tuberculosis Patients at an Indian Tertiary Care Center: A Descriptive Analysis. Plos One. 2018; 13: E0200838.

29. Manjareeka M, Palo SK, Swain S, Pati S and Pati S. Diabetes Mellitus among Newly Diagnosed Tuberculosis Patients in Tribal Odisha: An Exploratory Study. Journal of Clinical and Diagnostic Research : Jcdr. 2016; 10: Lc06-Lc8.

30. Van Crevel R, Ottenhoff TH and van Der Meer JW. Innate Immunity to Mycobacterium Tuberculosis. Clinical Microbiology Reviews. 2002; 15: 294-309.

31. Mahishale V, Avuthu S, Patil B, Lolly M, Eti A and Khan S. Effect of Poor Glycemic Control in Newly Diagnosed Patients with Smear-Positive Pulmonary Tuberculosis and Type-2 Diabetes Mellitus. Iranian Journal of Medical Sciences. 2017; 42: 144+. 